\title{
MANAGING INETEGRATED SYSTEMS OF INFORMATION STREAMS WITHIN AGRARIAN ENTERPRISES
}

\author{
Antonina Kalinichenko \\ Opole University, Poland \\ Olha Minkova, Victor Sakalo, Yuliia Vakulenko \\ Poltava State Agrarian Academy, Ukraine
}

\begin{abstract}
The system of making administrative decisions of agrarian enterprise in terms of its function in the informative space is analyzed. The conditions of system functioninG are formed and the system 's general component stages are grounded. The directions of informative streams are defined and the role of influential factors in the whole system`s effectiveness is determined.
\end{abstract}

Keywords: administrative decisions, system, information stream, technology, resources

DOI: $10.17512 /$ znpcz.2016.1.15

\section{Formulation of the problem}

Under the influence of constant changes in the conditions of the farmer's ménage, transformations in the decision-making process occur, and the processes of production management are revised. The steady increase of a leader`s responsibility for a given decision, complication of the position in the competitive environment, and the rise of technical progress` level require constant analysis of the technological processes for the purpose of defining the directions of guided influence. In such conditions, the information systems and streams move into the foreground. They can be applied as separate elements of the production system or as the links between system`s elements. In any case, the level of implementation of information systems visibly affects the system`s quality and makes its functions much more stable. That is why the formation and adaptation of the system of managing new information technologies appear to be a guaranty of improvement of agrarian enterprise.

\section{The analysis of the latest observations and publications}

In different works of scientists, i.e.: St. Beer, O. Kuzmin, G. Kunets, I. Morris, M. Starr, V. Shorin, M. Chumachenko, it's pointed out that the theory of decision making consists of mathematical system analysis, imitative modeling, heuristic methods of decisive reasoning, the game theory, the methods of expert evaluation, the algorithm of making decisions, and the management program for goals and results (Kuzmin, Mala, Melnyk, Protsyk., 2008, pp. 38-46; Mala 2007, pp. 20-24; Butynets, Shyhun 2004, pp. 86-94; Кунц, Доннел 1981, pp. 18-26; Бир 1965, pp. 41-54; Старp 1968, pp. 23-31; Чумаченко 2005, pp. 89-91). 
Having analyzed the functioning process of complex technological systems, it is possible to draw a conclusion that the main aspect which affects the correctness of a decision appears to be primarily entering information, its authenticity, topicality and fullness ( Нагірний, Бендера, Вольвак 2013, pp. 14-25). Considering the conditions for entering information it is expedient to build on requirements which are put on the very administrative decision (Vinogradskiy, Vinogradska, Shkanova 2003, pp. 101-106). Thus, the information must be opportune, which is provided by improving feedback between the object of administration and the governing body; it must have a clearly defined quantitative and qualitative expression, i.e. appropriate for analysis by means of known models and methods (Калініченко., Шмиголь, Шарун 2005, pp. 5-35), combined - to reflect all the changes in the process or a change of administrative object's state.

\section{Setting task}

The goal of the work is to define the directions of transformation of informative systems in the functioning of an administrative decision-making process in agrarian enterprises. The determination of the direction of information streams, external and internal, in relation to the system and environment, are the conditions the factors which are needed to be taken into consideration at different stages of the process of making administrative decisions.

\section{The presentation of the main material of the research}

The process of using informative systems in the agrarian sector may be divided into two main directions. The first is technical and technological creation of informative systems, which requires the permanent renovation of means and technologies of gaining and processing information. The second direction concerns methods of information usage.

If the first direction fully depends on scientific technical process and is closely connected with the requirements of technological processes in different fields of agricultural production, then the second direction is associated with human activity and depends on various subjective factors which can influence (positively or negatively) the level of new technologies implementation.

But there is the feature which combines both of directions mentioned below. This is their relation to the general theories of administration and systems. In any case, technological process may be introduced as a particular system. Such a system functions in accordance with structural unification of its elements.

The optimal functioning of machine-tractor unit in the field provides for the achievement of certain results. They are characterized by the optimality criteria (Калініченко 2005, pp. 15-22). For example, during operation of the drill for planting row crops we take into consideration the the following parameters: constancy of adherence to the norms of sowing seeds, uniformity of seed distribution along the row, and the depth of seeds in the soil. The evaluation of these factors and criterion can be the percentage of seeds that fall within the tolerance factor ( Сакало 2001). The purpose of the optimal functioning of the 
unit is the most accurate fulfillment of the conditions of optimality criteria. This provides a rational relationship between the impact on the environment and use of its natural potential.

The natural conditions of execution of the mechanized technological operations in the field are characterized by the coincidence of factors influencing the course of such operations. For example, during the execution of works on plant protection from pests and diseases, conditions for sedimentation of drops of liquid list of tables pesticides on plants surface change rapidly during the working day. It happens due to the power variation of the convection air flows and temperature modes. Such a change in time of statistical characteristics of factors determines the stationarity conditions of agricultural machinery work.

Therefore, it is necessary to have flow information of technological process. This is a prerequisite for the choice of action to optimize separately technology and operations. So use of computer systems in cars should ensure, as a first step, the control of the relevant optimization parameters.

It is difficult to foresee the behavior of most existing time-dependent factors on agricultural machines. Therefore, the machine operates in conditions of some uncertainty. Development of control actions on dynamic object, which is running in the face of uncertainty, is the basis of the principle of adaptation, and a dynamic object is attached to the state acting factors. Thus, adaptive dynamic objects significantly extend the range of conditions in which they performed the process.

Over the last years we have noticed a considerable progress in the development of information systems, which are designed for supervising the processes of technological system and are applied as an element of this system. As an example, we can take the systems which combine methods of production and technical devices for a control and administration of these devices` operation. It expanded the opportunities of a quick reaction on a change in technological process and improved the operative system administration.

In agrarian administration, the influence of external factors is characterized by fleeting changes of environment and appearance of unpredictable situational tasks, which require momentary reaction. The influence of internal factors may be regarded as a long-term component that is characterized by planned technological and structural transformations.

In these conditions, the head of enterprise cannot rely only on his intuition and approximate calculations. The decision and actions of administrative personnel should be based on accurate calculations, in-depth analysis of a problem, and then be scientifically proven, motivated, and optimized. No organizational, technical or technological action should be taken without defining its expediency.

Making administrative decisions, thereafter, occurs in incertitude, which cannot guarantee making the best choice of process or object`s development.

As a support in making administrative decisions, the principal technologies of analytical modeling are often used, that is: analysis of target function, parametric analysis, optimization analysis and prognostication based on exponential smoothing etc. (Gordienko 2003, pp. 147-151; Балджи, Карпов Ковальов 2014, pp. 84-95; Петруня, Говоруха, Літовченко 2012, pp. 145-168.) 
That is why the application of tools as models, which let optimizing parameters of technical means and technological equipment, planned load on technological sections, explaining the conditions for achieving and maintaining the needed intensity of production and, therefore, a necessary number of technical means and technological equipment appears to be an integral part of the decision-making system.

One of the main stages of development and realization of models is formalization of the enterprise's processes. Regardless of the scope, the way of designing and modeling of a complex system, it`s important to point out the primary stages of its formal description.

1. Making semantic description of an object or process and designing verbal model.

2. Dividing the system into eventual number of elements and forming components.

3. Designing mathematical model of the system and its further algorithmization.

The complexity in formation of a system task in functioning of engineering and technical service is that solving the questions of exploiting the technical means may be studied from different angles. On the one hand, production technologies require optimization processes. On the other hand, the general characteristics of equipment's usage must remain within the given allowance. It is also important to take into account the parallel usage and required reservation.

Thus, we can conclude that the manager must deal with both analytical and predictive planned activities.

The introduction of energy saving technologies in crop production has significant economic and environmental effects. When growing crops using different kinds of resources: natural (land, water, solar radiation), technical (tractors, agricultural machines and equipment) energy (fuel, electricity), process inputs (seeds, fertilizers, pesticides), labor and financial resources.

To justify a rational set of machines it is important to quantify the resources, using energy equivalent resources and productivity. This allows you to create an engineering task quantitative criteria and implement the principles of the system design technologies (figure 1). For each type of resourc you can use their methods and techniques of optimization entirely subjective to certain methods. Using a mathematical modeling system builds a foundation for decision making in agricultural production. It is impossible to consider separately certain resource problem of optimizing, because the impact of each of them on the final result is quite significant. Therefore, only a combination of the results of optimizing technical resources, financial, technological, based on external (natural) factors lead to loyal strategic decisions in agricultural production (Minkova, Sazonova, Sakalo, 2009, pp. 233-237.).

For example, if you explore the optimum number of employees serving technology for aggregates criterion for optimization of time, cost of labor, and energy consumption, it is necessary to develop a plan the best use of technology to meet all planned activities so that employment, economic or energy were minimal. To do this, the total number of units determine the best option for all jobs in conditions of full implementation of the planned amount of work (restriction 
on the area) timely implementation of the scope of work (time limit) use of available technology (limitation on the number of tractors and agricultural machines).

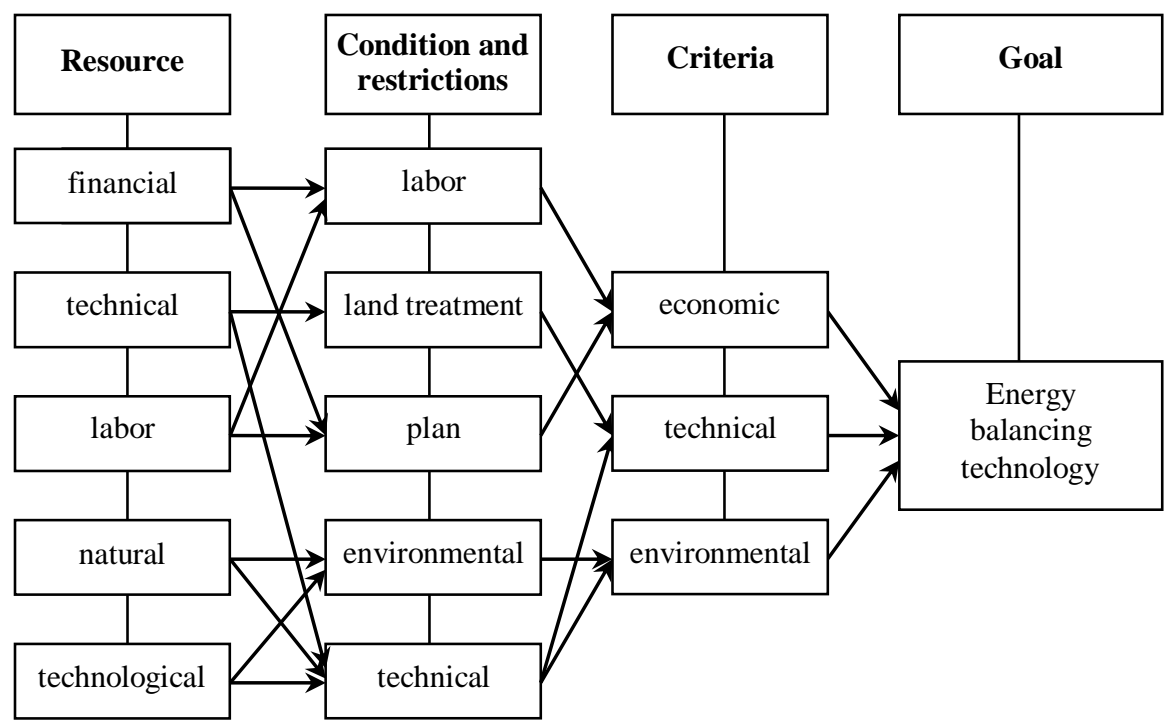

Figure 1. Structural-logical scheme optimization of production processes

Source: Own elaboration.

Given the patterns forming technology production phases can be formed management decisions for agricultural enterprises (figure 2).

The work of the leader cannot be without the analysis of the conditions of operation controlled object, setting goals, building structures monitoring processes flow production system as a whole and its individual components (agricultural machines, complex machines, repair shops, etc.). This requires adjustment feedback - information channels in compliance with all requirements for primary information received.

For this phase - analysis include the study of the resource base, structural and logical system of personnel management and foreign economic ties.

Receiving the initial information defined the operation goals justifying conditions and restrictions provided the real situation of the company, the engineering service manager conducts optimization process using known methods and techniques through simulation or purely intuitive method. The result of this process is clearly formed production model that aims to maximize profits or reduce operating costs, or achieve maximum environmental criteria, depending on the goals.

Besides, no model can be viewed only assuming its operation in ideal conditions. Changing the factors included in the model forms the area of risk changes and scenarios of development, especially their random, unpredictable 
variation. The system of making management decisions should include elements of forecasting, formation of various options for the fastest response when changing environment and internal components of the production system.

Considering the above-mentioned, the system of decision-making for agricultural enterprises might be seen as a combination of phases of analysis, optimization and forecasting.

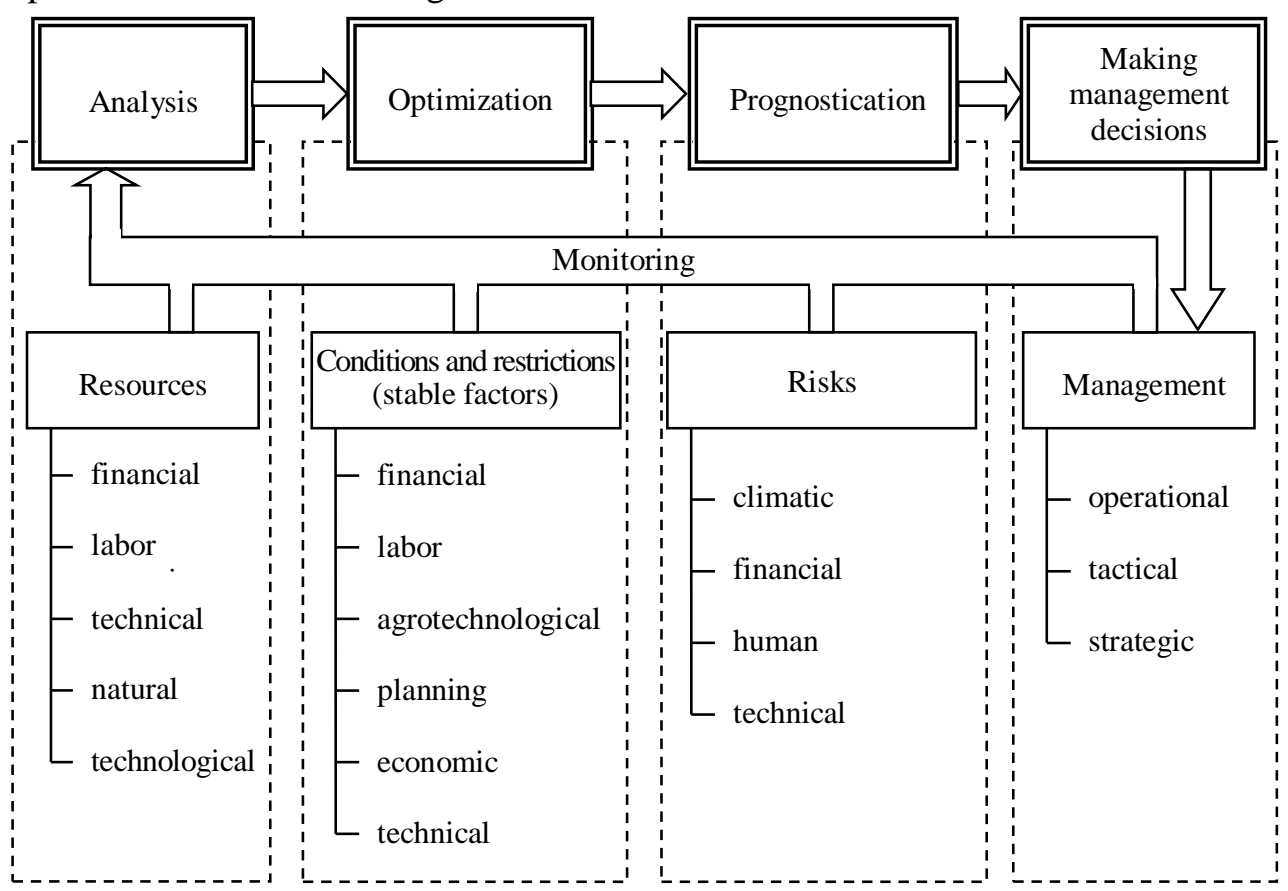

Figure 2. The system of decision-making agricultural enterprises

Source: Own elaboration.

But the usage information systems in this case can only be seen as an element of accumulation and processing of statistical information. Such using of information flows inherent to the low level of development or use of new information technologies. The information flow acts as a basic element or appreciating. It does not apply to the formation of the impact that corrects the course of technological process. Information forms the basis only change the whole system in case of not reaching the common goal of functioning. In other words, information systems are assigned a generalizing role. And essentially these systems are data characterizing the whole class or inherent reciprocal processes and phenomena. Their substance use is a meaningful understanding of the operation and the results compared with other similar processes. Understanding this problem is to change the structure or process elements. Such actions aimed at approaching characteristics of the studied process, to the standard features. 
On the other hand, information systems can act as generators during the control action of the system. With the development of scientific thought and technology realization methods of information processing appears the possibility of radical change in the concept of information flow inside the system. More accurate delineation becomes: 1) the operational management, 2) tactical and strategic management by operating technologies. The second is sent to planning of possibilities of enterprise with the aim of achievement of the put task.

Thus the system of acceptance of administrative decisions can be broken up on two subsystems. They are closely related between itself. Moreover, the subsystem of operative management largely forms streams for a tactical and strategic management (figure 3).

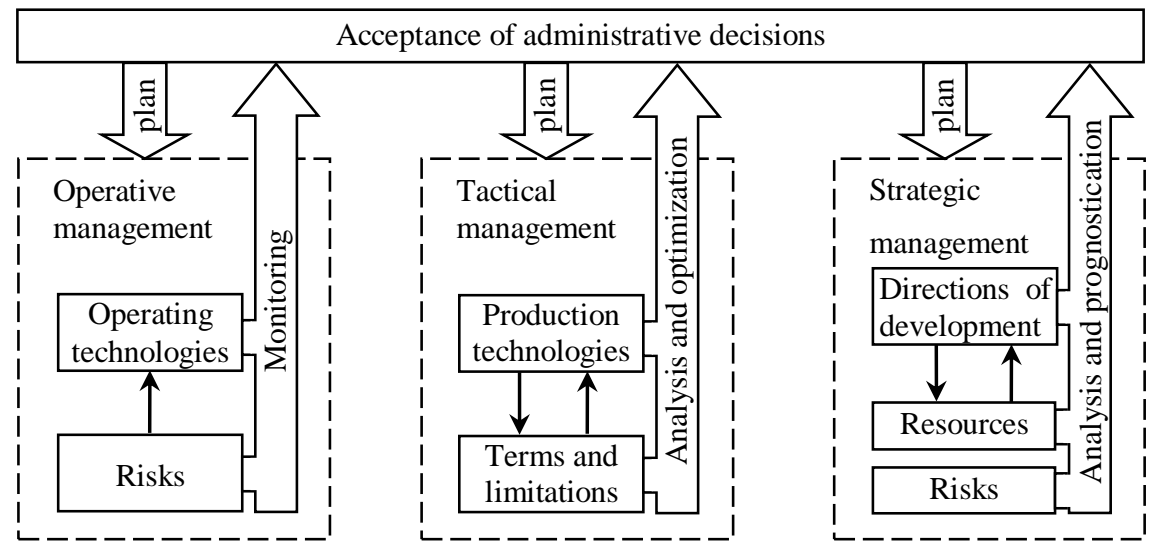

Figure 3. Integrating system of informative streams of agrarian enterprises

Source: Own elaboration.

Functioning of agrarian enterprise is foreseen by the stage-by-stage management of production technologies. At making decision on the stage of development of directions of development of enterprise the analysis of resources and possibilities is conducted. On the stage of tactical management technologies of production are formed. Select technologies are imposed by certain terms and limitation. And an operative management leans against operating technologies. Before, the analysis of implementation of technological operation was conducted at the receipt of result. Possibility to conduct monitoring of implementation of technological operation in the process of flowing of technological process appeared with appearance of new facilities of collection of information. It is also related to the improvement of executive mechanisms. Possibility to vary the parameters of flowing of technological process and began to control his motion by foundation for an operative management. Thus there is a process of accumulation of statistical information. He is used for forming of informative stream which is used for a tactical management. Also most risks are on an operative management. Such risks are related to the change of external operating of the system conditions. 
For example, sharp change of climatic terms, refuse of technique, error of the tactical planning, financial pressures, traumas, illnesses and others like that. Sure, part of such risks must be foreseen on more global stages of management. The degree of their impact reduced through redundancy and insurance. But backup cannot be limitless. Also monitoring of flowing of technological operation is included in the tasks of operative management. There is direct collection of the detailed information on this stage. It comes forward a primary informative stream for the system of acceptance of administrative decisions.

\section{Conclusions}

For the optimum operation of an enterprise it is necessary to build the dynamic system of acceptance of administrative decisions. Such system must take into account all permanent and variable factors. Acceptance of administrative decisions takes place on all three stages of management. Weight of operative management is considerably increased in a present tense, due to possibility of direct influence on a technological process. On the stage of operative management also there is direct collection of the detailed information. It comes forward a primary informative stream for the system of acceptance of administrative decisions. Present resources and select technologies are imposed by certain terms and limit on the choice of direction of development of enterprise. The proposed system must be adapted and adjusted during operation of a particular sector and be based both on integrated information systems, and the subjective assessments of processes of production.

\section{References}

1. Butynets F. F., Shyhun M. M., Models and methods of decision making in analysis and audit, Zhytomyr State Technological University, Zhytomyr, 2004, pp. 86-94.

2. Gordienko A. I., The informative systems and technologies are in a management, KNEU, Kyiv, 2003, pp. 147-151

3. Kuzmin O., Mala N. T., Melnyk O. G., Protsyk I. S., Leading Organization, NU «Lviv Polytechnic», Lviv, 2008, pp. 38-46.

4. Mala N. T., Administrative decisions: classification and process of acceptance, Announcer of the National university "Lviv politekhnika», Series Management and enterprise in Ukraine: stages of becoming and problem of development, No. 605, WELL «Lviv politekhnika», Lviv, 2007, pp. 20-24.

5. Minkova O.G., Sazonova N. A., Sakalo I. M., Criteria of estimation of influence of agricultural production on the state of agroekosistem, Announcer KHNTUSG: Economic sciences, Vol. 92, KHNTUSG, Kharkiv, 2009, pp. 233-237.

6. Vinogradskiy M. D., Vinogradska A. M., Shkanova O. M., Organization of labour of manager, «Condor», Kyiv, 2003, pp. 101-106.

7. Балджи М. Д., Карпов В. А., Ковальов А. І. та ін. Обтрунтування господарських рішень та оиінка ризиків, ОНЕУ, Одеса, 2014, pp. 84-95.

8. Бир Ст., Кибернетика и управление производством, Наука, Москва, 1965, pp. 41-54.

9. Калініченко А. В., Оптимальне використання земельних ресурсів - надійний засіб досягнення збалансованості агроекосистем, Агроекологічний журнал, № 1, 2005, pp. 15-22. 
10. Калініченко А. В., Шмиголь Ю. В., Шарун Т. А., Методи прийняття ефективних рішень у аграрному виробництві, Київ, 2005, pp. 5-35.

11. Кунц Г., Доннел С., Управление: системный и ситуащионный аналіз управленческих функиий, Прогресс, Москва, 1981, pp. 18-26.

12. Нагірний Ю. П., Бендера І. М., Вольвак С. Ф., Аналіз технологічних систем і обтрунтування рімень, ред. Ю. П. Нагірного, ФОП Сисин О. В., Кам'янецьПодільський, 2013,pp. 14-25.

13. Петруня Ю. Є., Говоруха В. Б., Літовченко Б. В. та ін., Прийняття управлінських рішень, ред. Ю. Є. Петруні, Центр учбової літератури, Київ, 2012, pp. 145-168.

14. Сакало В. М., Пристрій для контролю характеристик сільськогосподарських матеріалів, Патент 40984А України, А01В69/04, Опубліковано 15.08.2001, Бюлетень № 7.

15. Старр М., Управление производством, Прогресс, Москва, 1968, pp. 23-31.

16. Чумаченко М., Економічна думка в розвитку: досягнення $і$ проблеми, Економіка Украӥни, № 5, 2005, pp. 89-91.

\section{PODEJMOWANIE DECYZJI ADMINISTRACYJNYCH JAKO SYSTEM INTEGRACYJNY STRUMIENI INFORMACYJNYCH PRZEDSIĘBIORSTW ROLNYCH}

Streszczenie: W opracowaniu przeanalizowano system podejmowania decyzji administracyjnych przedsiębiorstwa rolnego pod względem jego funkcjonowania w przestrzeni informacyjnej. Sformułowano warunki funkcjonowania systemu i wyjaśniono ogólne etapy składowe systemu. Zdefiniowano kierunki strumieni informacyjnych i określono rolę czynników wpływających na skuteczność całego systemu.

Słowa kluczowe: decyzje administracyjne, system, strumień informacyjny, technologia, zasoby 